\title{
Notes on Swedish Forest Biogeochemistry - Investigations During 50 Years
}

\author{
Folke O. Andersson
}

Department of Ecology, Swedish University of Agricultural Sciences, PO Box 7044, SE-750 07 Uppsala, Sweden; e-mail:folke.andersson@slu.se

\begin{abstract}
Andersoon F.O. 2015: Notes on Swedish Forest Biogeochemistry - Investigations During 50 Years. - Beskydy, 8 (2): 111-121

This paper gives an overview of biogeochemical investigations performed in forests by the author during more than 50 years - from the start of the academic carrier up to the present day. An interesting feature is that old investigations have been published again with addition of new data. Some results are presented in a short way illustrating tools for integration and synthesis, such as carbon budgets of single trees as well as whole forest ecosystem. The value of long-term observations is discussed as well as the emergence of a new science, ecosystem ecology.
\end{abstract}

Keywords: tree biomass, production, mineral cycling, budgets

\section{Introduction}

Forest biogeochemistry has been a key area of interest for Professor emeritus Emil Klimo. This paper deals with the same area and is a review, rather personal, of research efforts carried out during the last half century in Sweden by the author and collaborators. Over the years a number of environments have been subject to investigations, either as individual projects or team projects.

The start was in 1958 with investigations of water relations, which resulted in research on differentiation of flora and vegetation, soil physical and chemical factors leading to investigations of biogeochemistry of an oak forest, meadows and fens in a nature reservation - Linnebjer. This was done close to my university in Lund, Southern Sweden. It resulted in a doctoral thesis (Andersson 1970a, b and c). Recently, now almost 60 years later, some parts of the early investigations have been repeated in order to find out possible changes during this period (Andersson, Nihlgård 2016).

In 1970 the time became ripe to be involved in large-scale ecosystem research, which was initiated as a consequence of the activities of the International Biological Programme - IBP. A project on the Swedish Northern Coniferous Forest (SWECON) was launched (Persson 1980) and was run 1973-1981. The main research area was in Central Sweden - Ivantjärnsheden, Jädarås, a Scots pine forest on sandy soil. At this time there was also an interest in Czechoslovakia for this kind of projects. Emil Klimo visited our project in order to study how to establish similar activities. He had also an interest in our research as such and spent a sabbatical leave with us.

A typical demand for Swedish biogeochemical research has been that hypothesis need to be tested with experiments. Examples of Swedish forest experiments are given in Table 1 (Andersson, Lundqvist 1988).

During 1977-1982 I was not only one of the leaders of the SWECON-project, but also responsible for the air pollution or acid rain research at the Swedish Environmental Protection Board. A project, the Gardsjö project, was launched dealing with a comparison of an acidified, un-limed lake and a limed lake as well as to quantify, in numerical terms, the sources to acidification of a lake (Andersson, Olsson 1985). The latter investigation needed a biogeochemical approach. 
Tab. 1: Swedish forest experiments related to nutrient addition, liming and fertigation

\begin{tabular}{|c|c|c|c|c|c|c|}
\hline & Långban & Bleckstugan & Norrliden & Ivantjärnshegen & Hasslöv & Skogaby \\
\hline Start & 1913 & 1959 & 1971 & 1973 & 1984 & 1988 \\
\hline Tree age & Unknown & 96 & 20 & 20 & 35 & 23 \\
\hline Species & $\begin{array}{l}\text { Norway } \\
\text { spruce }\end{array}$ & Scots pine & Scots pine & Scots pine & $\begin{array}{l}\text { Norway } \\
\text { spruce }\end{array}$ & $\begin{array}{l}\text { Norway } \\
\text { spruce }\end{array}$ \\
\hline Design & $\begin{array}{c}\text { Reps. Soil } \\
\text { No reps. trees }\end{array}$ & Factorial & Factorial & Factorial & Factorial & Factorial \\
\hline Treatment & $\begin{array}{l}\text { Liming } \\
10 \text { t.ha }^{-1}\end{array}$ & $\begin{array}{l}\text { Liming } 10 \text { t.ha }^{-1} \\
\text { NPK }\end{array}$ & $\begin{array}{c}\text { Liming } 5 \mathrm{t}_{\mathrm{ha}} \mathrm{ha}^{-1} \\
\mathrm{H}_{2} \mathrm{SO}_{4}\end{array}$ & $\begin{array}{l}\text { I - Irrigation } \\
\text { F-NPK, IF }\end{array}$ & $\begin{array}{c}\text { Liming } 1.6 \\
\text { t.ha- }^{-1} \\
\text { Dolomite } \\
\text { K-line }\end{array}$ & $\begin{array}{c}\text { NS, NSD, IF } \\
\text { D, V, A }\end{array}$ \\
\hline
\end{tabular}

The emergence of ecosystem science became a realty (Coleman 2010) during the IBP-time. My experience from these years and as an ecosystem ecologist has been given as a "testimony" in "Terrestrial Ecosystem Ecology - theory and applications" (Ågren, Andersson 2012), now a textbook in use in Brno.

\section{Material and methods}

Material and methods used for these investigations are given in the references presented in the previous section.

\section{Results and discussion}

The investigations reported in the previous papers are many and diverse. Therefore only a few findings will be briefly reported related to the theme of the day - biogeochemical cycling. The purpose is to give examples of tools, which can be used for integration and syntheses within the area.

\section{Linnebjer}

Linnebjer is today a Natura 2000 area (Figure 1). A Special area was subject to detailed investigations (Figure 2) and the of ground water gave here rise to two different regimes of water movement - in the forest one vertical movement and in the lower parts of the meadow and fens a horizontal movement of importance for chemical effects on the soils.

The investigations with time also included biogeochemical cycling. The results were published in 1981 (Reichle 1981). Data is there available in a data bank, included in the reference cited. As the publication was incomplete a final publication was done recently (Andersson 2014). It dealt with plant biomass, primary production and mineral cycling. The paper contains information on carbon, nitrogen and sulphur. The biogeochemical cycling is discussed out from a schematic model (see Figure 3 and Table 2).

Old investigations, when repeated, have the advantage that changes can be registered. In Linnebjer it could be concluded that the tree layer of the oak forest had changed as an oak disease had developed and affected the tree layer. Further, soil chemical analyses revealed that a soil acidification had continued with losses of calcium and magnesium as a consequence of deposition of sulphate (Table 3 and 4). The leached elements from the forest were found in the humus layer of the meadow and fens. However, the present levels of sulphate are low and nitrogen still high.

\section{Ivantjärnsheden}

The research area was a Scots pine forest on sandy soil. An age series of forests was identified (Figure 4). A variety of investigations were carried out, among them tree physiology studies with gas exchange measurements. These were done in an experimental area including control, fertigation (fertilizer composed according to the need of the tree and dissolved in water), irrigation and fertilisation with solid fertilizer.

The fertigation in operation can be seen in a photo as well as the vegetation response after eight years (Figure 6). Budgets are common in biogeochemistry. A specific one is here related to a carbon budget for a young pine tree (Ågren et al. 1980). The carbon uptake by the tree is balanced by the utilization (Table 6). The latter was used as follows: respiration of stem and branches $4 \%$ and roots $6 \%$, growth of stem, branches and needles $33 \%$ and of roots $57 \%$. Below-ground processes are still less known.

The SWECON-project resulted in a number of results during 1972-1981: 15 professors, more than 200 papers in reviewed scientific publications and 150 reports (SWECON - Reports and publications, 1984). 


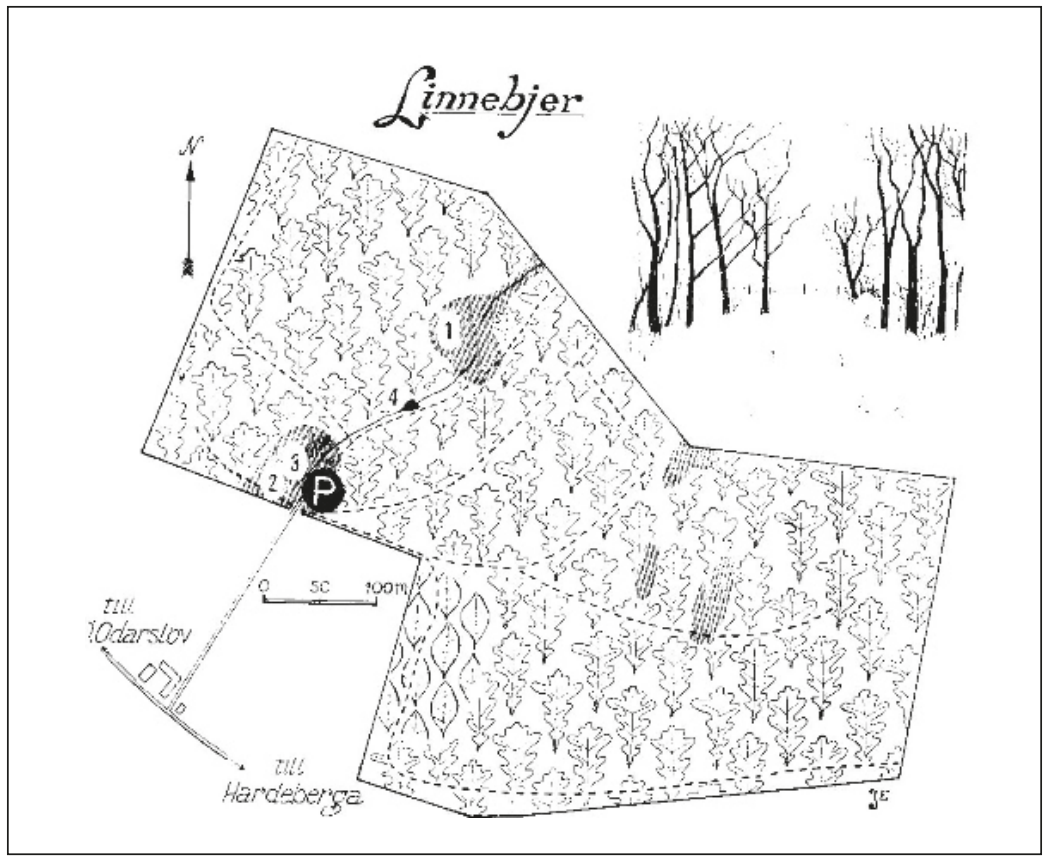

Fig. 1: Linnebjer, S Sweden. Pictorial map of the nature reserve. From: Andersson 1966

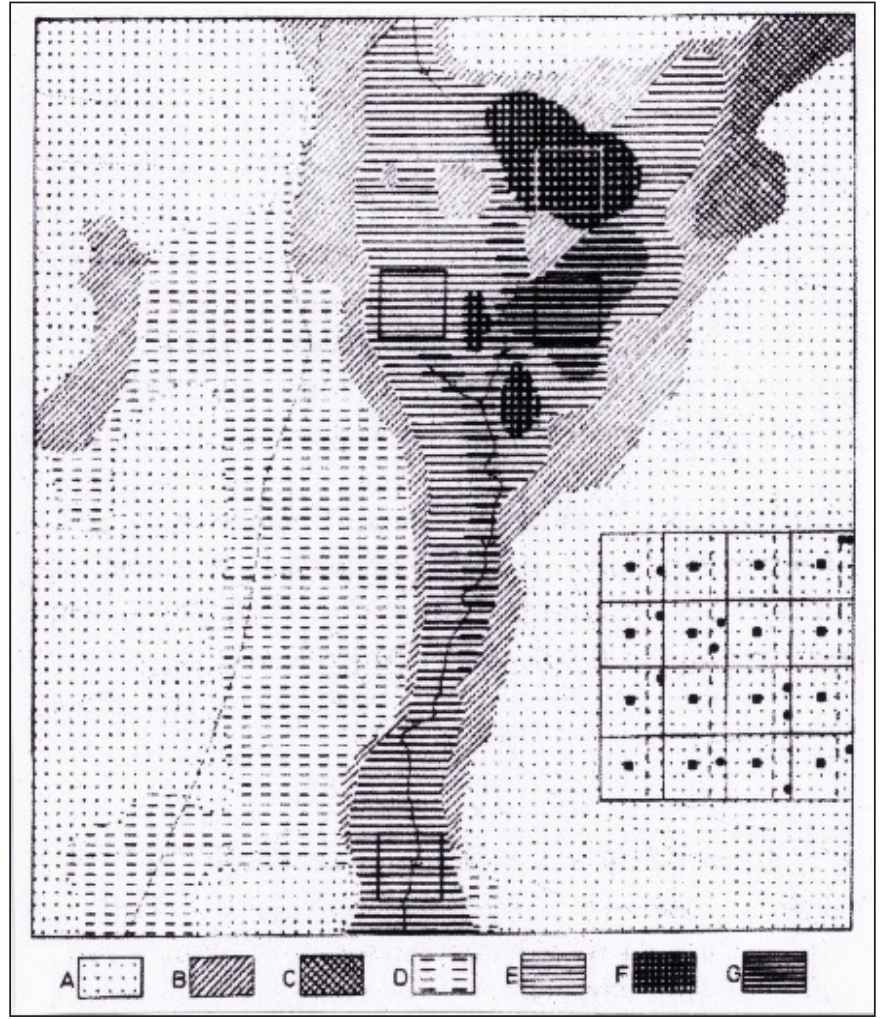

Fig. 2: Linnebjer, S Sweden. Map of the Special area with ecosystem types. A. Oak forest; E. Filipendula meadow; F. Carex flacca fen; G. Carex caespitosa fen. From: Andersson $1970 b$ 


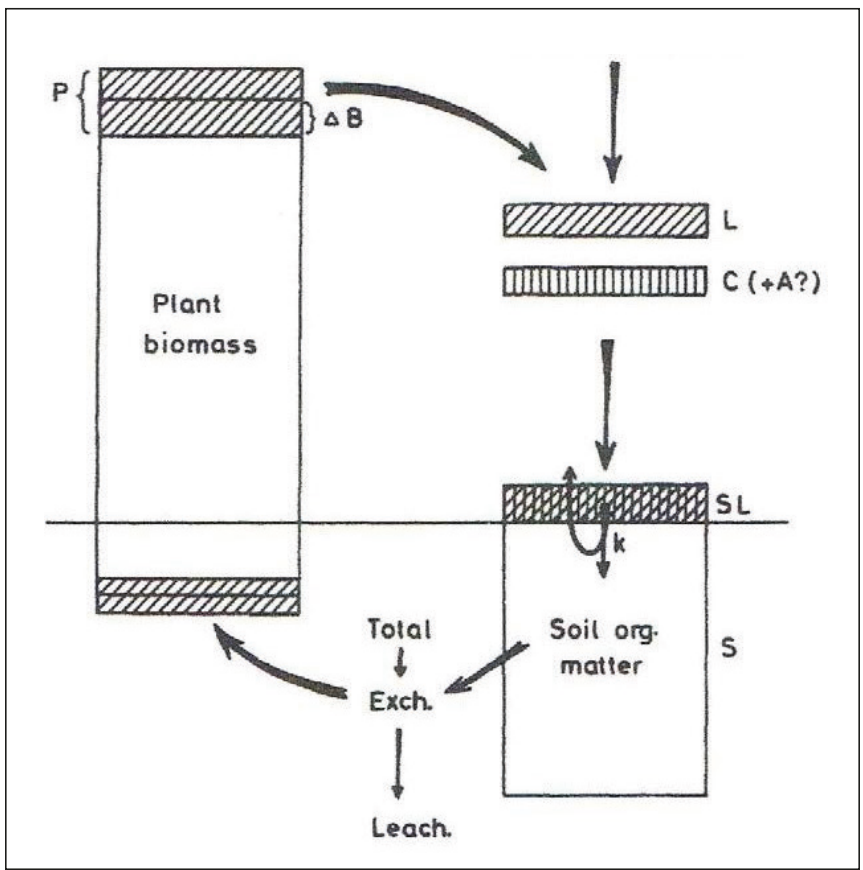

Fig. 3: Schematic model of organic matter and mineral cycling. Explanations: P-Production; $\triangle B$ - Change in biomass; C - Current leaves; SL - Surface litter; $k$ - Decomposition rate; Total amounts of elements; Exch - Exchangeable amounts of elements; Leach-Leaching. From: Andersson 2014

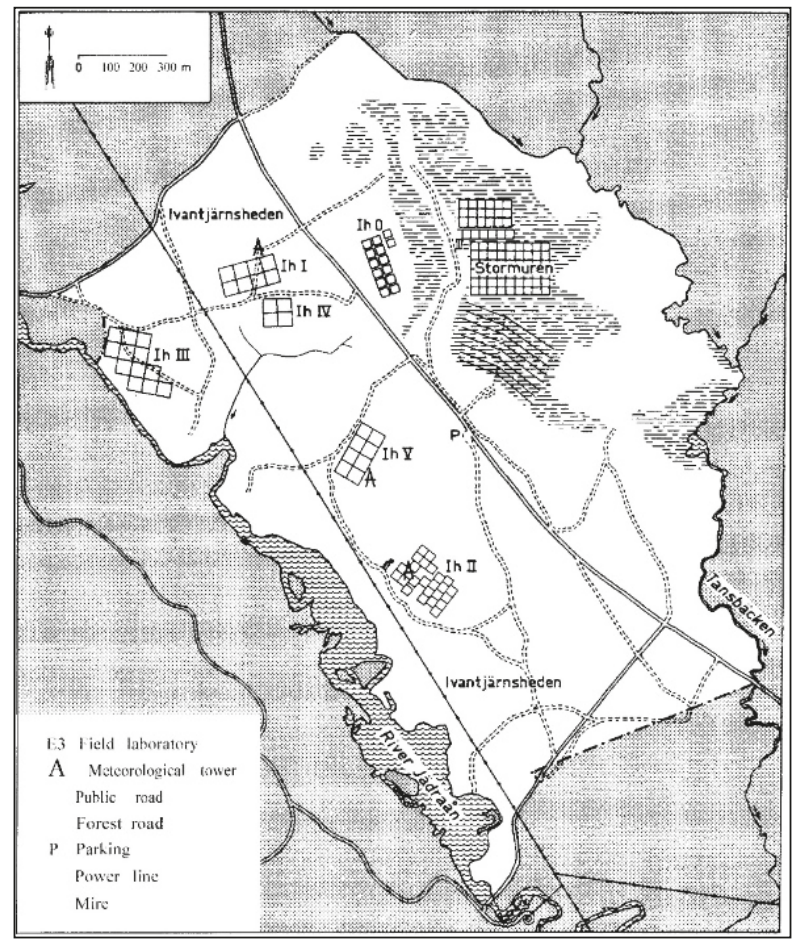

Fig. 4: Ivantjärnsheden, Jädraås. C Sweden. Research area of the SWECON project. A cronosequens of Scots pine forests (h 0-IV) selected for investigations. From: Persson 1980 


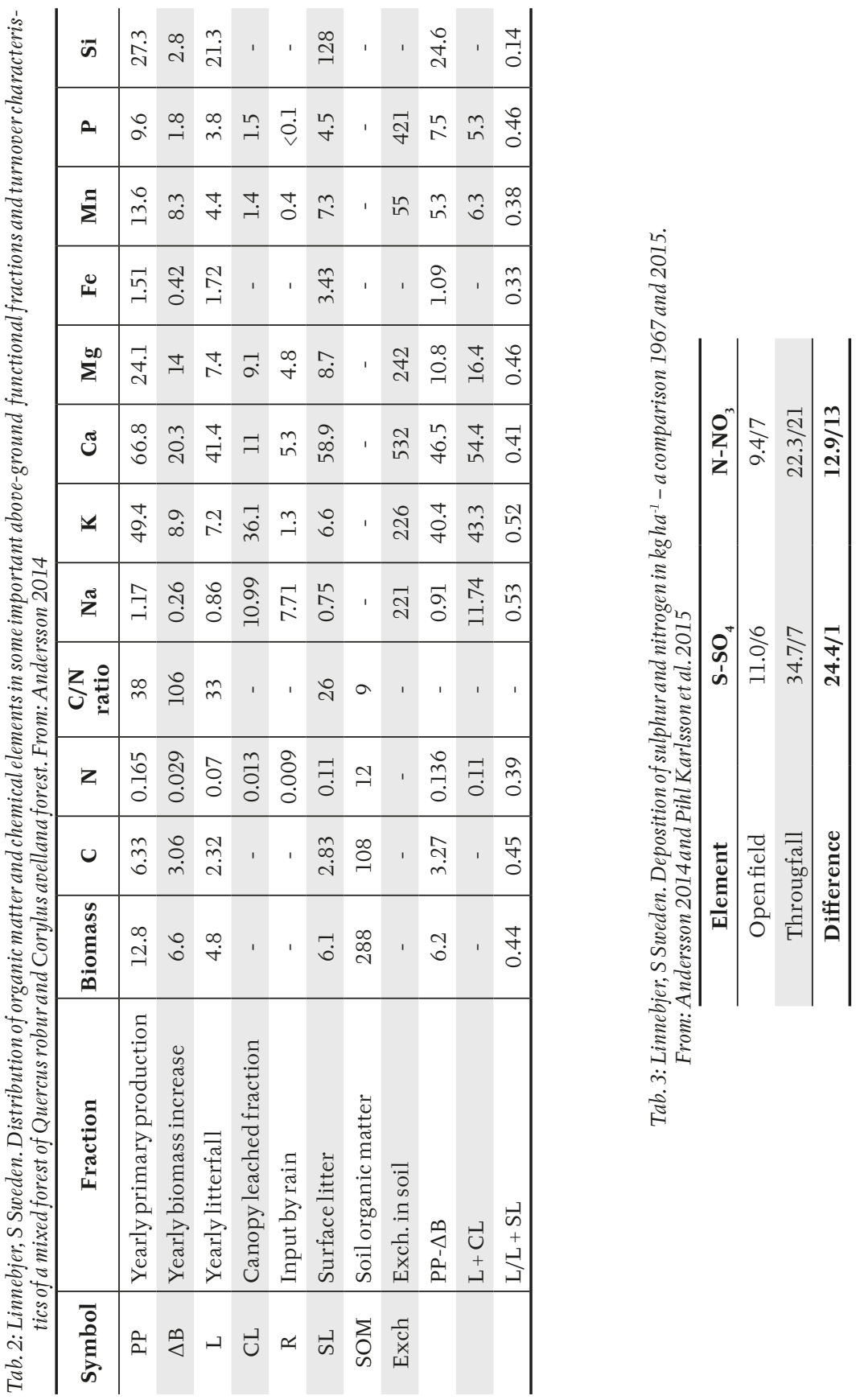




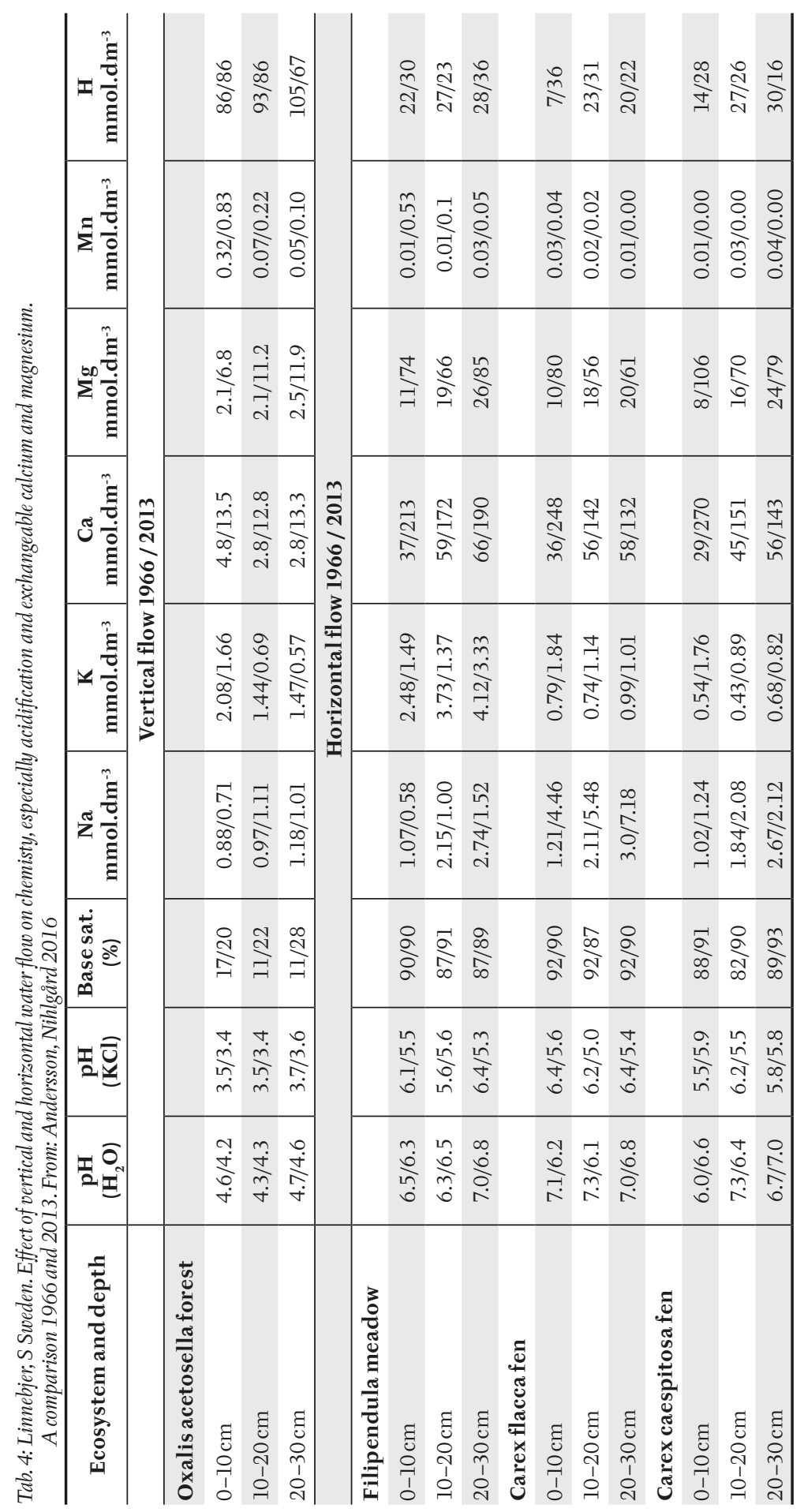




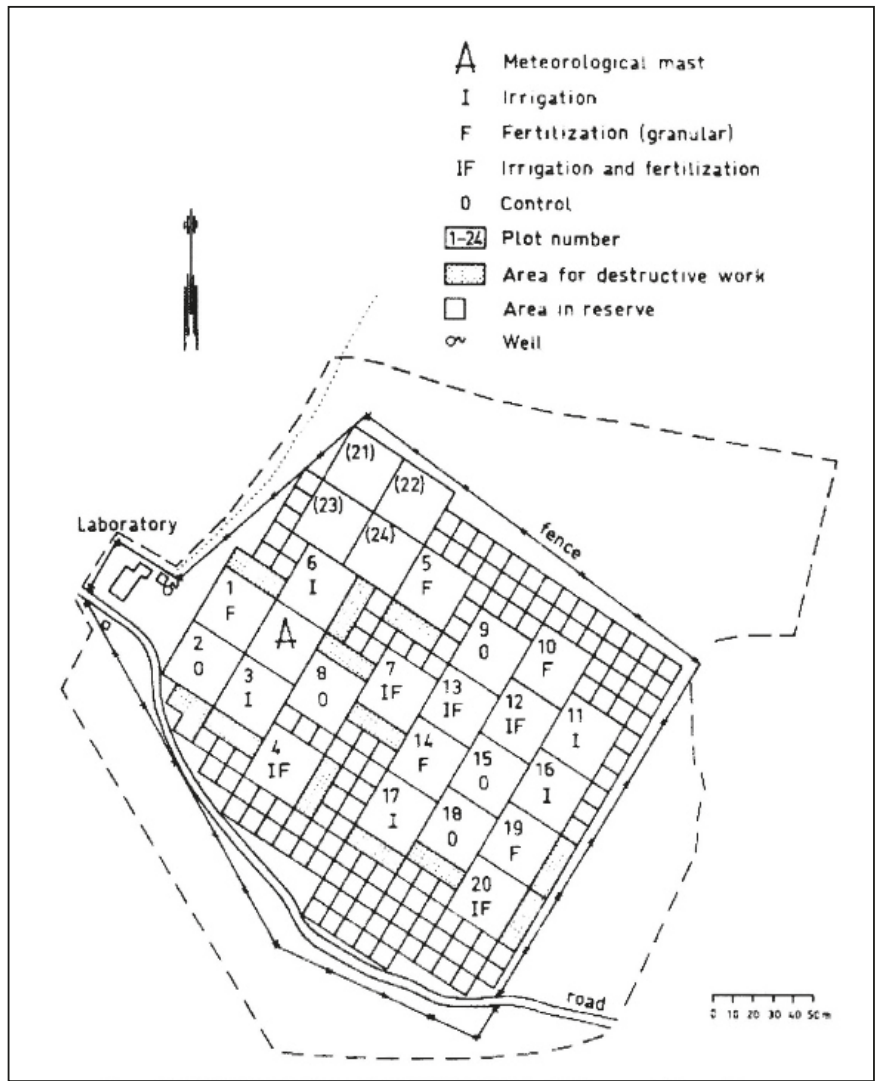

Fig. 5: Ivantjärnsheden, Jädraås. C Sweden. Experimental area of Ih II and its treatments. O - Control; IF-Fertigation (Irrigation + Fertilization); F- Solid fertilizer. From: Persson 1980

Tab. 5: Ivantjärnsheden, Jädraås. C Sweden. A carbon budget for a young tree Scots pine-a balance of production, respiration and growth. From: Agren et al. 1980

\begin{tabular}{|c|c|c|c|}
\hline & $\begin{array}{l}\text { Carbon uptake } \\
\left(\mathrm{gC}_{\mathrm{yr}}^{-1}\right)\end{array}$ & $\begin{array}{c}\text { Carbon utilization } \\
\left(\mathrm{gC}^{\left.-\mathrm{yr}^{-1}\right)}\right.\end{array}$ & $(\%)$ \\
\hline Net photosynthetic production & 1723 & & \\
\hline Respiration & & 173 & 10 \\
\hline - Stem, non-needle-bearing part & & 49 & 2.9 \\
\hline - Branch-axes, non-needle-bearing parts & & 15 & 0.9 \\
\hline - Roots & & 109 & 6.4 \\
\hline Growth & & 1523 & 90 \\
\hline - Stem & & 145 & 8.5 \\
\hline - Branch-axes & & 132 & 7.8 \\
\hline - Current needles & & 286 & 16.9 \\
\hline - Roots & & 960 & 56.6 \\
\hline Total utilization & & 1696 & 100 \\
\hline
\end{tabular}




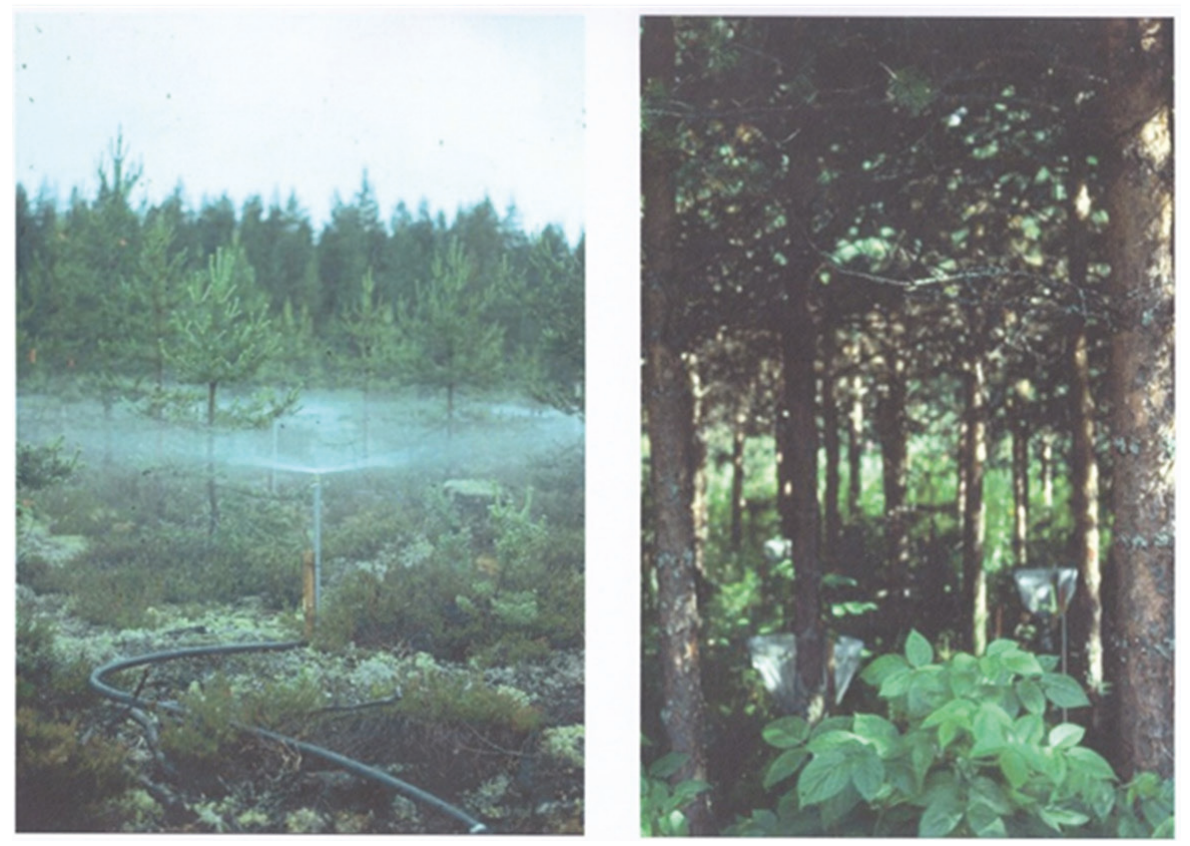

Fig. 6: Ivantiärnsheden, Jädraås, C Sweden. Experimental areas Ih II. Photo of a sprinkler system for fertigation. Effects on vegetation after 8 years. Note Rubus idaeus. Photo: Sune Linder.

\section{Gårdsjön}

The Gårdsjö area is situated N of Gothenburg on the west coast - an area with previously high deposition of sulphur and now also of nitrogen. The area has shallow soils of moraine and on acid bedrock. Considering earlier experiences the area was suitable for further investigations. A project was started comparing an acid, nonlimed lake and a limed lake. A second aim was to quantify the sources of acidification of the lake.

In order to derive, in quantitative terms, the sources to lake acidification a budget approach had to be used. Processes leading to input and output from micro-catchments had to be measured and converted into protons or hydrogen ions to be compared with the output/losses of protons from the drainage area (Nilsson 1985). It was concluded that $40-55 \%$ of the protons to the lake came from atmospheric deposition to the soil (Table 6). The lake acidification was most likely caused by direct input of protons to the lake surface and increased sulphate flux from the soil to the lake caused by leaching due to sulphate ions.

Tab. 6: Gårdsjön, W Sweden. Balance of proton sources and sinks of in a mixed conifer forest. Results in keq $\mathrm{H}^{+} h \mathrm{~h}^{-1} \mathrm{yr}^{-1}$

\begin{tabular}{lccc}
\hline & Proton sources & & Proton sinks \\
\hline Wet deposition of $\mathrm{H}^{+}$ & 0.5 & $\mathrm{H}^{+}$output & 0.5 \\
SO deposition & 0.5 & $\mathrm{NH}_{4}^{+}$output & 0.0 \\
$\mathrm{NH}_{4}^{+}$deposition & $0.6-0.8$ & $\mathrm{NO}_{3}^{-}$deposition & $0.6-0.8$ \\
$\mathrm{NO}_{3}^{-}$output & 0.0 & $\begin{array}{c}\text { Accumulation of anions in } \\
\text { biomass }\end{array}$ & 0.0 \\
$\begin{array}{l}\text { Accumulation of base cations in } \\
\text { biomass }\end{array}$ & 0.6 & Weathering & $1.6-2.3$ \\
$\begin{array}{l}\text { Dissociation of base cations in } \\
\text { biomass }\end{array}$ & $0.4-0.6$ & Sum & $\mathbf{2 . 7 - 3 . 6}$ \\
\hline Sum & $\mathbf{2 . 6 - 3 . 0}$ & & \\
\hline
\end{tabular}




\section{Skogaby}

The Skogaby experiment was started in order to reveal the causes of "forest damage" - a complex scientific issue dealing with the interaction between climate and tree nutrition (Andersson 1989). The experiment was done in a 23 year old Norway spruce forest. It included control, drought (roof), irrigation, nitrogen+sulphur addition, vitality fertilization, ash addition and various combinations with drought (Figure 7).

So far only the effects on the long-term addition of nitrogen and sulphur has been analysed
(Persson, Nilsson 2001). The growth reaction of the tree layer in terms of basal area growth and dry matter production up to 2000 showed that fertigation (IF) gave the highest response and culminated in 1992 followed by irrigation and nitrogen+sulphur addition (Figure 8 and 9). The latter declined compared to control after 1996.

As an example for element cycling of carbon and nitrogen in a young Norway spruce forest material has been taken from this investigation (Figure 9) (Ågren, Andersson 2012).

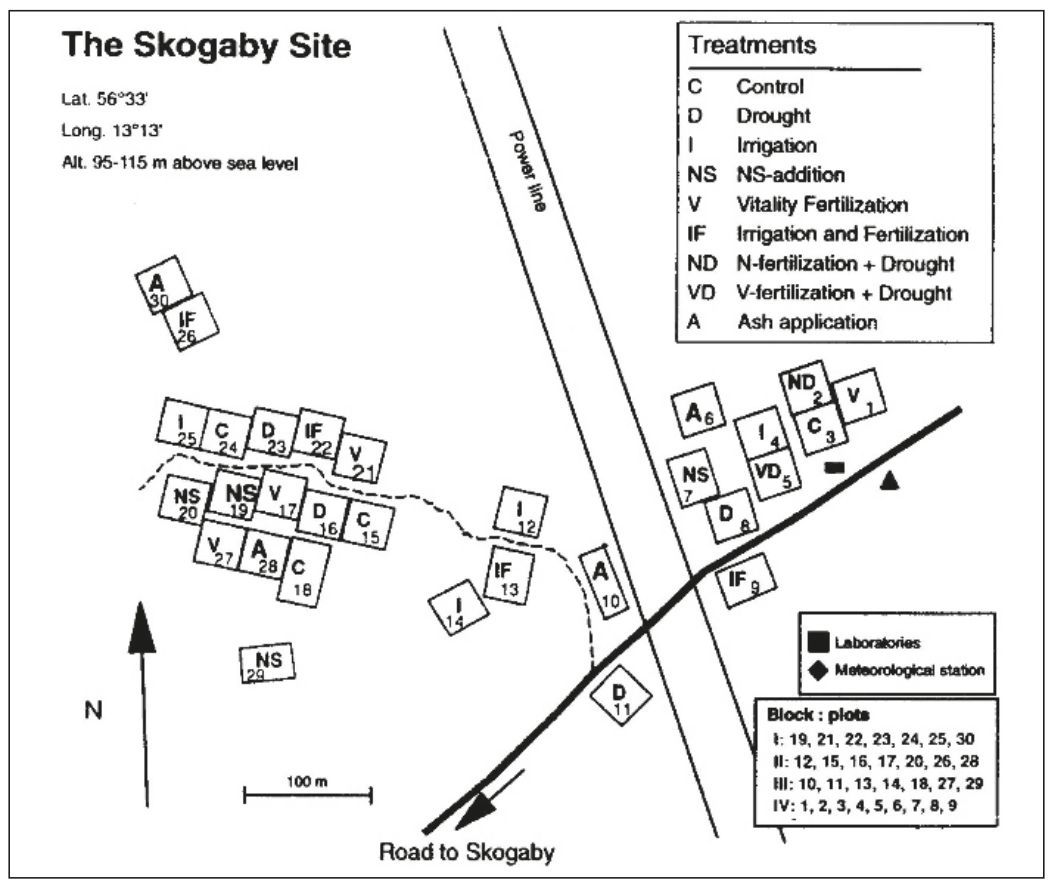

Fig. 7: Skogaby, W Sweden. Map of the experimental area with four replicates and their treatments. C - Control; D - Drought; I - Irrigation; NS - Nitrogen and ammonium addition; $V$-Vitality fertilization+Drought. From: Persson, Nilsson 2001.

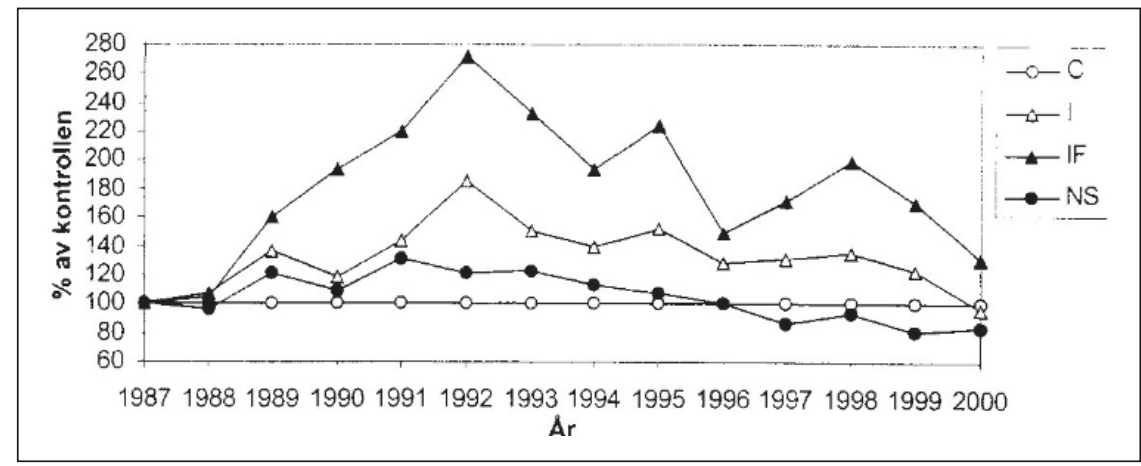

Fig. 8: Skogaby, W Sweden. Effects of irrigation (I), Fertigation (IF) and addition of nitrogen and ammonium (NS) on tree growth expressed as basal area growth relative to control. From: Persson, Nilsson 2001 


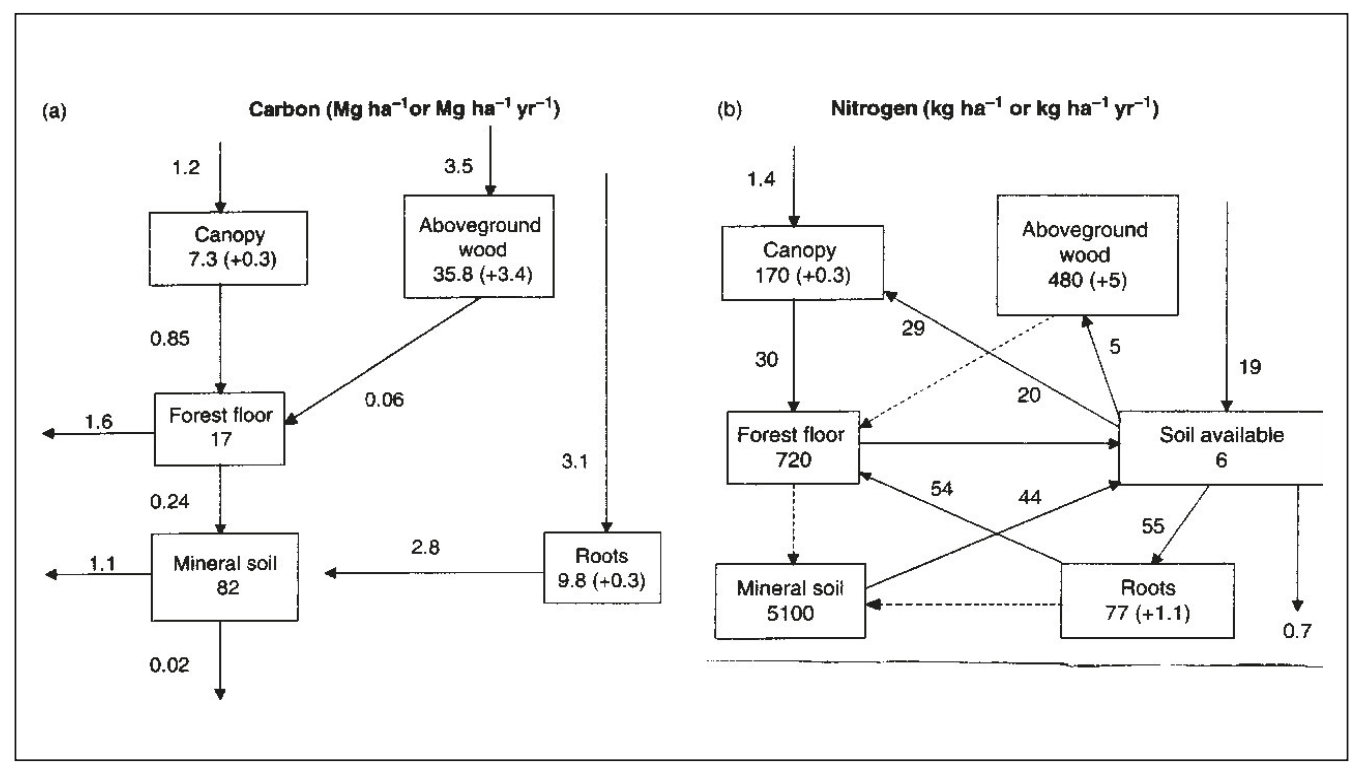

Fig. 9: Skogaby, W Sweden. Carbon and nitrogen cycling of a young Norway spruce forest. From: Ågren, Andersson 2012

\section{Hestehave}

The author has also been involved in the Danish IBP-project - an investigation of a mature Danish beech forest. The first biogeochemical results were given in a report by the author (in Thamdrup 1973). A revision of tree biomass and production was done in 2014. A considerable growth increase had occurred during the period 1967-2014 (Andersson 2015). The increased deposition of nitrogen could be a contributing factor (Table 7).

\section{Conclusion}

This paper reports, in a condensed form, research activities relating to the field of forest biogeochemistry, where the author has been involved for more than half a century. Different kinds of budgets are referred to: tree budgets and ecosystem budgets for various elements. The paper mentions also how a new discipline of ecosystem ecology has developed and been accepted.

Tab. 7: Tree biomass, production, carbon and nitrogen dynamics over a 44-year perspective in a European beech forest (Hestehave, Jutland, Denmark). Data for 1970 compared with data from 2014 based on a remeasured tree diameter applied in previous allometric regressions. Element content in 2014 was assumed to be the same as in 1970.

\begin{tabular}{|c|c|c|c|c|c|c|c|c|c|c|}
\hline \multirow{2}{*}{$\begin{array}{c}\text { Fraction } \\
\text { Year }\end{array}$} & \multicolumn{2}{|c|}{$\begin{array}{c}\text { Tree biomass } \\
\text { t.ha }^{-1}\end{array}$} & \multicolumn{2}{|c|}{\begin{tabular}{|c|} 
Tree production \\
t.ha $^{-1}$
\end{tabular}} & \multicolumn{2}{|c|}{$\begin{array}{c}\text { Carbon } \\
\text { t.ha }^{-1}\end{array}$} & \multicolumn{2}{|c|}{$\begin{array}{c}\text { Nitrogen } \\
\text { kg.ha-1 }\end{array}$} & \multicolumn{2}{|c|}{$\begin{array}{l}\text { Sulphur } \\
\text { kg.ha-1 }\end{array}$} \\
\hline & 1970 & 2014 & 1970 & 2014 & 1970 & 2014 & 1970 & 2014 & 1970 & 2014 \\
\hline Stem wood & 163.0 & 388.2 & 4.5 & 11.0 & 77.3 & 184.0 & 163 & 388 & 17.8 & 42.9 \\
\hline Stem bark & 7.4 & 13.6 & 0.22 & 0.5 & 3.1 & 5.7 & 54 & 99 & 4.1 & 7.5 \\
\hline Branches & 46.9 & 133.2 & 5.7 & 5.1 & 19.2 & 54.2 & 207 & 588 & 15.5 & 44.0 \\
\hline $\begin{array}{l}\text { Current } \\
\text { twigs } \\
\end{array}$ & 3.0 & 3.9 & 3.0 & 3.9 & 1.4 & 1.4 & 51 & 66 & 3.8 & 4.9 \\
\hline Sum & 220.3 & 538.9 & 13.42 & 20.5 & 101 & 245.3 & 475 & 1141 & 41.2 & 98.8 \\
\hline
\end{tabular}




\section{Literature}

Ågren, G.I., Andersson, F. 2012: Terrestrial Ecosystem Ecology - Principles for a young Scots pine. Applications. Cambridge University Press, 330 pp.

Ågren, G.I., Axelsson, B., Flower Ellis, J.G.K., Linder, S., Persson, H., Staaf, H. 1980: Annual carbon budget for a young Scots pine. In: Structure and Function of Northern Coniferous Forests. (Ed. Persson, T.). Ecological Bulletins, 36: 307-313.

Andersson, F. 1966: Linnebjer. Treasures in Skåne IX. Skånes Natur, 53: 1-5. Lund. (In Swedish. Klenoder i Skåne IX).

AnDersson, F. 1970a: An Ecosystem Approach to Vegetation, Environment and Organic Matter of a Mixed Woodland and Meadow Area. Thesis, Lund.

ANDERSSON, F. 1970b: Ecological Studies in a Scanian Woodland and Meadow Area, Southern Sweden. I. Vegetational and Environmental Structure. Opera Botanica 27, 190 pp.

ANDERSSON, F. 1970c: Ecological Studies in a Scanian Woodland and Meadow Area, Southern Sweden. II. Plant Biomass, Primary Production and Turnover of Organic Matter. Botaniska Notiser, 123: 8-51.

Andersson, F. 1989: A Field Experimental Approach to Understanding of Forest Damage. In: (Eds. Klimo, E., Materna, J.). Verification of Hypotheses on the Mechanisms of Damage and Possibilities of Recovery of Forest Ecosystems. Report from a Workshop, 156-168.

Andersson, F. 2014: Plant Biomass, Primary Production and Mineral Cycling of a Mixed Oak Forest in Linnebjer, Sweden. Open Journal of Forestry, 4: 570-580.

Andersson, F. 2015: Cycling of carbon and other elements in a beech forest Hestehave, Jutland, in the past 50 years. Open Journal of Forestry, 5: 296-312.

Andersson, F., LundQvist, H. 1989: Research Strategies for long-term Site Productivity. In: /Eds. Dyck, W.J., Mess, C.A./. Proceedings IEA/ BE A3 Report, No. 8: 125-137.

Andersson, F., Nihlg̊̊rd, B. 2016: Linnebjer A South Swedish Forest and Meadow Area revisited after 50 years. Open Journal of Ecology. (In print)

Andersson, F., Olsson, B. 1985: Lake Gårdsjön - An Acid Forest Lake and its Catchment. Ecological Bulletins, 37: $336 \mathrm{pp}$.

Coleman, D.C. 1985: Big ecology - The emergence of Ecosystem Science. University of California Press, $236 \mathrm{pp}$.
Persson, T., Nilsson, L.O. 2001: The Skogaby experiment - effects of long-term addition of nitrogen and sulphur to a forest ecosystem. With summary in English. (In Swedish: Skogabyförsöket Effekter av långvarig kväve-och svaveltillförsel till ett skogsekosystem). Naturvårdsverket Rapport 5173. Stockholm, 220 pp.

Pinl-Karlsson, G., Akselsson, C., Karlsson, P.E., Hellsten. S. 2015: Net of througfall measurements 1985-2015 - monitoring of air pollution and its effects on forest soils. (In Swedish; Krondroppsnätet 1985-2015 - tre decennier med övervakning av luftföroreningar och dess effekter på skogsmark. IVL Rapport C 127. Göteborg, $27 \mathrm{pp}$.

ReICHLE, D.E. 1981: Dynamic Properties of Forest Ecosystems. International Biological Programme 23. Cambridge University Press. 683 pp.

SWECON, 1984: Reports and publications. Report 14, Department of Ecology and Environmental Research, Swedish University of Agricultural Sciences. Uppsala. 135 pp.

Thamdrup, H.M. 1973: The Danish IBP Woodland Project. In: Modelling Forest Ecosystems. Report of IBP Woodland Workshop, IBP/PT Section, 14-26 August 1972. Oak Ridge Report EDFBIBP 747: 231-250. 